\title{
The Borderland in the System of Contemporary INTERNATIONAL RElations: the SECURITY Aspect
}

\section{Pogranicze w systemie współczesnych stosunków międzynarodowych: aspekt bezpieczeństwa}

\begin{abstract}
The previous century brought to humanity many political trials. Nowadays, we witness new challenges to world security and stability. Besides, borderlands play a compelling role in the political processes of modernity. Some political actors, like the Russian Federation, try to keep and strengthen their influence at the expense of other states, including Ukraine. Therefore, a transformation of an aggressive policy of such players, from military to hybrid, provoke the surrounding world to think: what's next?
\end{abstract}

Keywords: borderland, challenges, geopolitics, democracy.

Abstrakt: Miniony wiek przynióst ludzkości wiele przemian politycznych. W dzisiejszych czasach jesteśmy świadkami nowych wyzwań dla bezpieczeństwa $i$ stabilności na świecie. Dodatkowo istotna role w politycznych procesach czasów nowożytnych odgrywaja tereny pogranicza. Niektórzy aktorzy sceny politycznej, jak Federacja Rosyjska, staraja się utrzymać i wzmocnić swoje wptywy kosztem innych państw, w tym Ukrainy. Dlatego też transformacja agresywnej polityki takich graczy, z militarnej na hybrydowa, skłania obserwujacy świat do zadawania pytań: co dalej?

Słowa kluczowe: pogranicze, wyzwania, geopolityka, demokracja

1 Dr Nataliya Nechaieva-Yuriichuk, Yuriy Fed'kovych Chernivtsi National University, e-mail: n.nechayeva-yuriychuk@chnu.edu.ua, ORCID: 0000-0001-5882-7121 


\section{Introduction}

One of the most actual problems of nowadays is security. At the end of thelast decade, the term "security" acquired a new meaning. The fast-spreading of Covid-19 brought new challenges in our lives, especially for both personal and collective security. The World Health Organization (WHO) announced a pandemic of Covid-19 in early March 2020, and the main reason of that was "alarming level of inaction" over the virus (Coronavirus 2020). During the following months, a growing number of casualties could be observed in different states all over the world. Out of Western democracies, Italy, and Spain were between the fist states where the highest amount of casualties of Covid-19 was reported. But in the following months the other countries like the USA and Brazil "took the lead" in this impressive, sad statistics (Covid-19 2020).

The situation is threatening to every person, every community, every state and the world as a whole. It is possible to find the different versions and explanations of how the virus has come to be, its spread, symptoms etc. but nobody can precisely predict the development of the situation. It is even possible to find dictionaries of coronavirus in different languages, both official (A Guide 2020) and unofficial (Karantyn 2020). Many instances of misinformation concerning coronavirus appeared in different media after February 2020. They were not only journalistic sensations, or social media users' private mistakes. In our opinion, it was a deliberate campaign to weaken democratic foundations of the world, first of all in the EU, and in the USA. The aim of it was (and probably still is) to make the whole world disappointed with democratic governments' struggle against Covid-19 pandemic. The way of spreading such idea is very simple: during the pandemic, a significant number of various fake news concerning coronavirus appeared, and number of articles reporting successful fight of authoritarian regimes against the virus were published (Vostochnoe povetrye 2020; SMY 2020; Kytaiskye Predprynymately 2020). Such narrative was spread in the world information space via media, including social media. The danger of this narrative lies in its subversive essence: the threat to life is equated with the wrong choice of political regime. As the Russian expert on international affairs Aleksei Naumov said, "after the end of the coronavirus pandemic, the focusing on promoting democracy in the world as the basis of foreign policy will be more difficult for the United States" (Vostochnoe Povetrye 2020). Probably that's why a unit to combat Russian 
misinformation about the coronavirus was created in Great Britain in March 2020 (U Velykii Brytanii 2020).

So, the strong relation between geopolitics and pandemic is visible. And the Russian Federation continues to play its destructive role for contemporary world order. A provocative and radical activity of the Russian Federation has been visible for a long period of time. But after the Revolution of Dignity in Ukraine, Russia's aggressive policy has become more visible and tangible to the rest of the world, and the borderland is crucial in this policy.

During the Covid-19 pandemic, borderlands felt changes both in internal and in the foreign policy of their home states and neighbouring states. First of all, the closing of borders highly influenced all spheres of life of borderland inhabitants. Besides, any interference of foreign governments in its internal affairs influences political and even economic stability for a region separately and the state as a whole. Of course, it affects the ethnoand socio-political stability in the region as a whole (for example, Central and Eastern Europe, the European Union etc.)

Ukraine is one of the states that have experienced the expansion and replenishment of the concept of security. For the last ten years, Ukrainian citizens have identified the term "security" with individual and collective protection in economic, political, and military spheres, and, of course, in health care. It seems that in recent days, the questions of health care should be in the first place. But as far as the last sociological data certify, more than $30 \%$ of Ukrainians believes that coronavirus had been artificially created and deliberately distributed in the world to reduce the population (U Shtuchne Pokhodzhennia 2020). This testifies the growing influence of disinformation and conspiracy theory which are spread by different media, including social media. In Ukraine, they are often spread by Russian or Russian-language media, probably because the Russian language is still popular and well-known here. Thus, the security problem today is always connected with the information component. Neglecting the information component can lead to security breaches at all levels, from the personal to the global. So, prevention of security challenges is possible in case of in-depth analysis of reasons for peculiarities of current processes in all spheres of life of the world community.

Ukrainian citizens, like citizens of many world countries, recognize the threat of separatism, the growth of extremism, the confrontation between different regions of Ukraine, and international terrorism (Hromadiany 
Ukrainy 2015). For the last decade, the state felt a strong interference in its internal and foreign affairs, first of all by the Russian Federation, but some signs of that had been obvious since the collapse of the USSR.

That is why the main aim of the article is the analysis of the place of borderland in contemporary geopolitics on the example of the aggressive policy of the Russian Federation toward former Soviet republics, like Moldova, Georgia, and Ukraine.

\section{Moldova: the First Repetition of Geopolitical Changes at the End of XX Century}

After the collapse of the USSR, the radical changes on the political map of the world have occurred. It seemed like the world had had to become multipolar. But at the end of the XX century and at the beginning of XXI, the changes have been occurring very fast. To be honest, two big political actors like the Russian Federation (RF) and the USA were trying to keep their influence on the entire world. Of course, there were much more political actors, but as far as we witness now, these two are still trying to keep their political influence via traditional instruments. Of course, the EU, China etc. started to play a much more significant role in world's socio-economy processes, but our attention will be focused on RF and its attempts to keep post-Soviet space in its sphere of influence.

Perestroika (rebuilding or reconstructing of Soviet system) proclaimed by M.Gorbachev, was intended to become a start of renewed Soviet Union. In fact, it provoked the processes of national revival throughout the Soviet state, including in Soviet Moldova. The foundations of contemporary Transnistrian separatism in Moldova were pledged by the Soviet centre in 1920-s. For us, it came to life because of the main principle of Soviet national policy which aimed to use internationalism (as the main principle of Sovietism) against any "manifestations of nationalism". Probably that's why the national composition of the population in Moldova of 1926 could not help but cause surprise and likelihood of aggravation of the ethnic situation in future (Moldovans amounted only around 30,1\% of the total population while Ukrainians, for example, more than $48 \%$, Russians, 8,5\%) ( (Tuchynskyi 2011: 255). The final borders of Soviet Moldova were formed in 1940 and, after the collapse of the USSR, they settled 
as the state borders of independent Moldova: (a grey zone is contemporary Transnistria):

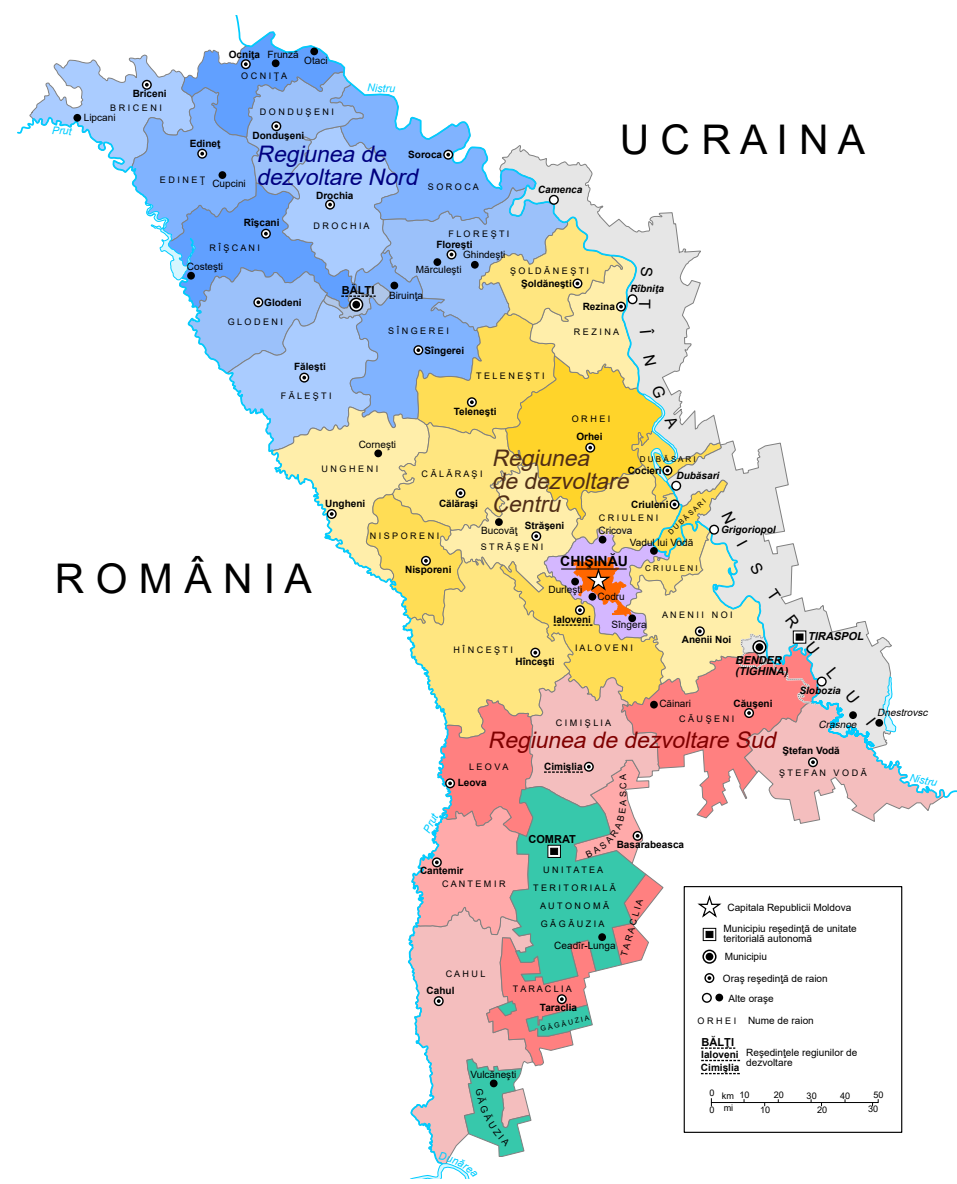

Map 1. Administrative map of the Republic of Moldova

During the Soviet period, the national composition of the population of the Republic of Moldova had changed. On the one hand, the number of Moldovans increased. On the other hand, the processes of russification were so strong all over the USSR, that the Russian language became not only the language of mutual understanding but also the official language for party communication, both internal and inter-republican. It was also being used for party communication with people. Even today, almost 30 years after the collapse of the USSR Russian language is still 
used for communication in Moldova (mainly on a personal level, but also by officials in Transnistria, Gagauzia, for instance).

For Moldovans, the perestroika also meant the aggravation of contradictions between different self-identities within a Moldovan society. So far, those contradictions have still being used by different political powers in their activity. First of all, we mean the supporters of so-called "unionism" and "moldovenism". In the span of the last decades the first one transformed into so-called "neo-unionism", but at the end of 1980-s - beginning 1990-s that ideological division played a destructive role for ethnopolitical stability in the republic.

The attempt to punish Russian-speaking people by making them to learn Moldavian (or Romanian which is now recognised as the state language in Moldova) and to turn Moldova to the historical roots which unite it with Romania spread the feeling of fear between those who did not know the language. And what was the worst: they wanted to keep the Soviet reality, especially in the language sphere. Ideological confrontation found its reflection in the political sphere. The first multiparty elections of 1990 led to a new configuration of political actors in Moldova's parliament. The People's Front (opposing the Communist party) won 27\% of all votes. The political discussion in parliament walls became hotter, and the movement of the republic out of the USSR toward Romania became more pronounced. Changes to the alphabet along with further changes to the national flag, anthem and national emblem were to symbolise a new political reality. Condemnation of the coup in 1991 was the first step toward independence. But at the same time, the separatist movement has started to function in the republic.

The first separatist step was made by Gagauzia in November 1989. The Extraordinary Congress of Gagauzian people proclaimed autonomy. They created the Gagauzian Autonomy Soviet Socialist Republic as part of Moldova. For the next several years Gagauzia tried to keep the autonomy and even proclaimed itself as the part of the USSR. But the geopolitical situation has changed. In fact, the military confrontation between Chisinau and Komrat was avoided. In December 1994, the document about the peaceful integration of Gagauzia into Moldova on autonomy basis was signed between Gagauzian and Moldovan authorities. It got wide autonomy rights included in the Constitution of the Republic of Moldova. Till summer 1995, Gagauzian Republic was transformed into Autonomy formation Gagauzia - Gagauz Eri. This case needs more specific attention, 
but till now Gagauzia has had a strong influence on the decision-making process in Moldova. It is on guard of protection of neutrality status of the republic, and its change can lead to aggravation of separatism here. The last is in political interests of the Russian Federation, and it is used for sharing historical and political ideas via many events, including scientific, cultural etc. in Gagauzia. The language of communication here is still mainly Russian (not Gagauzian).

The history of Transnistria autonomy started in September 1989. The independence of Transnistria was proclaimed on August 25, 1991. The historical roots, reasons, consequences etc. were deeply analysed by researchers from different states including Moldova, Ukraine, Romania, Russia etc. From the early beginning till nowadays Transnistria got military and financial support from the Russian Federation (at the beginning through the presence of Soviet troops, and, after 1991, Russian). The last was crucial for state integrity of Moldova. Today Transnistria is an unrecognized state and its political elite is not only oriented on Moscow. It is really dependent on it.

The events in Ukraine in 2014 demonstrated that political hopes and political reality for Transnistria political elite are different. After the Crimea annexation in April 2014, the Parliament of Transnistria appealed to Russian Federation authorities to recognise their independence. But if RF was going to do it, why they did not do it in 1991? RF confirmed its position toward Transnistria by neglecting their appeal. It doesn't need independent Transnistria. Russia was and still is not going to include it into the federation. It is possible to suppose that the chief value of Transnistria to Russia is the possibility to influence on Chisinau foreign policy under the pressure of either territorial collapse of the state or economic default. In this context, the question about Transnistria debt for gas was not raised accidentally by Russian vice-minister Dmitriy Rogozin. From our point of view, this meant that Russia is afraid to lose its influence on Moldova and to keep it in the sphere of its influence trying to use Transnistria again as the lever on Chisinau authorities. 


\section{2008 Russia-Georgia War as a Manifestation of the First Open Hybrid War for post-Soviet Space}

At the beginning of the last millennium, the world faced a growing number of inter-ethnic and interstate conflicts. Nowadays, the world community witnessed many social, economic, politic, and, as it was mentioned before, health care problems. It seems that the issues of borderland in the Caucasus are not on the first place on the world political agenda, but the role and connections between events in Moldova, Caucasus, Ukraine, Syria, Spain, Scotland need more scientific attention with practical recommendations and the development of useful algorithms to counter modern military information aggression.

The Caucasian theme keeps the attention of many scientists all over the world. Between Ukrainian authors, it necessary to point out the joint work of Alla Kyrydon and Serhii Troian (Kyrydon, Troian 2009)2 , who soon after the Russian aggression analysed the influence of the conflict on Ukraine.

Every case in ethnic relations needs some historical investigation. The relations within the triangle Russia - Georgia - Abkhazia and South Ossetia (as a common case in this separated situation) were difficult and complicated during the centuries. Incorporating Georgia into the USSR brought new possibilities and challenges for this Caucasian republic. The formation of boundaries was also conducted taking into account the national factor as a kind of deterrent and counterbalance to "preserve the interethnic balance" in the Soviet Union.

At the beginning of 1990-s Abkhazia and South Ossetia proclaimed its independence from Georgia. The military conflict did not solve the problem. During the following period of more than ten years, there was no reaction of the international community to "independence" of those territories. And only in 2006 Abkhazia and South Ossetia recognised the independence of each other. Officially, Tbilisi did not recognise that.

2 At the beginning of the last millennium, the world faced a growing number of inter-ethnic and interstate conflicts. Nowadays, the world community witnessed many social, economic, politic, and, as it was mentioned before, health care problems. It seems that the issues of borderland in the Caucasus are not on the first place on the world political agenda, but the role and connections between events in Moldova, Caucasus, Ukraine, Syria, Spain, Scotland need more scientific attention with practical recommendations and the development of useful algorithms to counter modern military information aggression. 
The "independence" of those territories was strongly encouraged by the Russian Federation. And the procedure of getting Russian citizenship for people from Abkhazia and South Ossetia was used by RF for strengthening its positions in the region.

Eventually, all that led to the armed conflict between Russia and Georgia in August 2008. It wasn't just a military conflict. In modern history it entered as the "lightning war", but in information spear, it was the start of a new epoch for Russia aggressive politics.

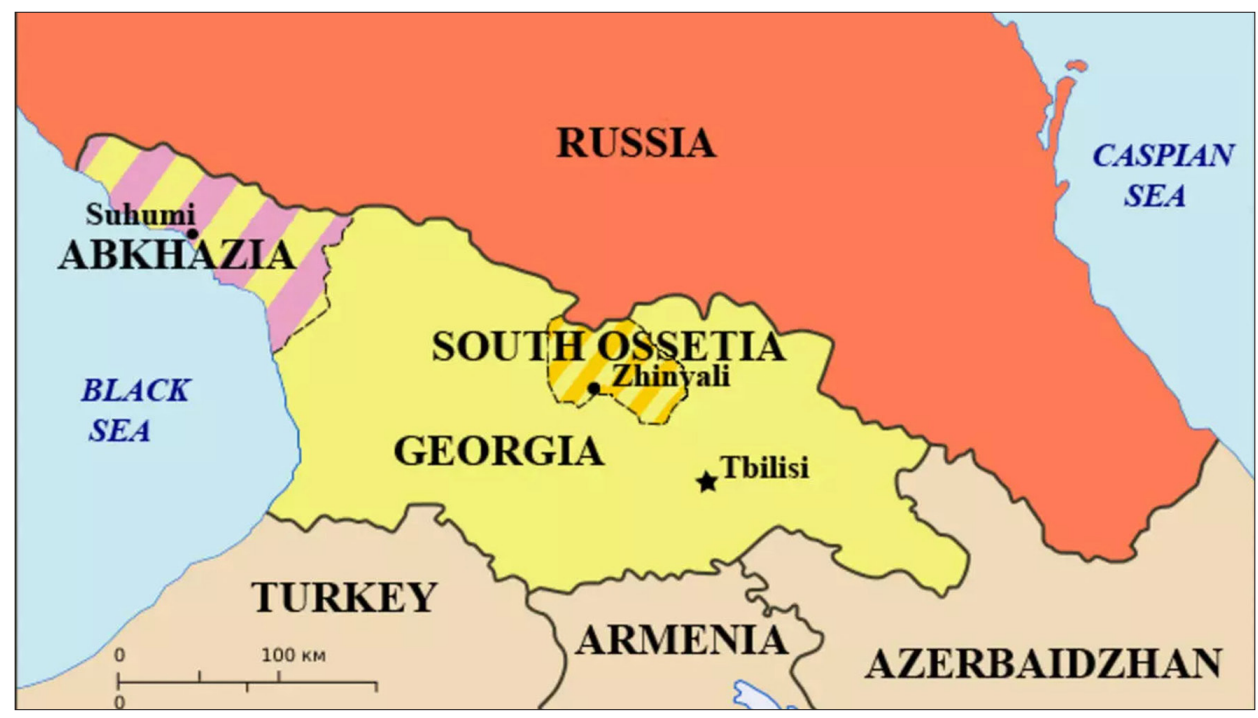

Map 2. Caucasian Region

The information concept of the Russian Federation was the creating image of Russia as the "state-peace-keeper" and it was spread in the world via Russian TV (First Channel, RTR etc.) The main idea of all TV plots and other propagandistic materials was that all Russian-speaking people must unite to win the war with "nazi Georgia". The Saakashvili's posters demonstrate the chief message of Russian propaganda in war 2008: the whole world should unite against the repeating of the Second World war horrors. For this purpose, Russian propaganda used well-known images of the Second World war to make a psychological link between the events of the mid-XX century and 2008. Special attention was dedicated to the Georgian President Michael Saakashvili: 


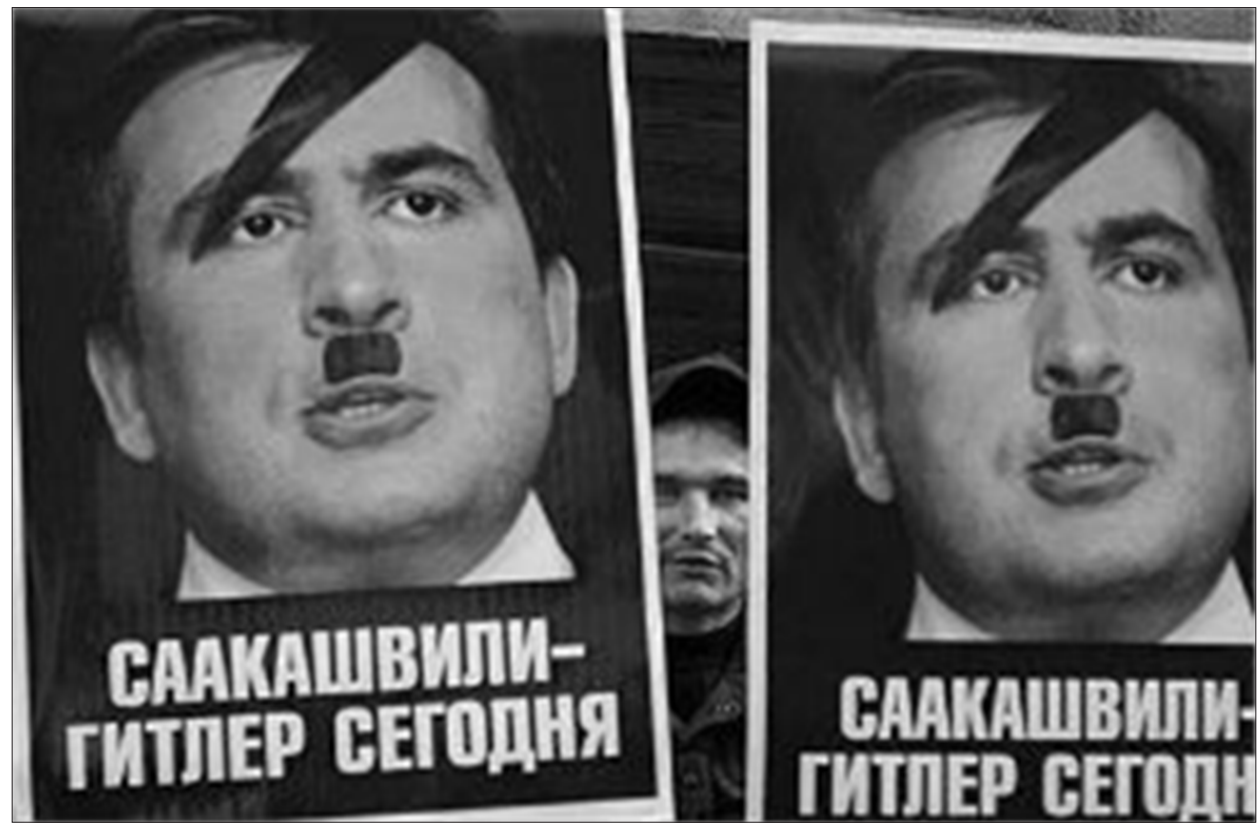

Graphic 1. Michael Saakashvili

During the first days of the war, the monopoly on information about the events in the Caucasus was held by the Russian side. Russian media shared the information about the number of victims, and now it is clear that it exaggerated the number of casualties in Tskhinvali to justify the actions of Russian authorities. Due to the lack of alternative sources, many world channels as far as Ukrainian ones got information about those days from Russian resources (internet, information agencies, TV, etc.). The first independent information on the number of victims in South Ossetia appeared only on August 13. It was provided by international organizations.

Unlike Russians, the Georgian side was unprepared to the information war. A large amount of information about the war was in the Georgian language, so the international community had difficulties in understanding it, as there are not enough translators of this language. Thus, it was particularly troublesome for the other countries to provide high-level synchronic translation in English of many national and regional Georgian media. So, foreign media, including Ukrainian, had to use other available sources or to wait for information from their own correspondents. It was reflected in TV storylines of Ukrainian television news. 
The war immediately became the most important event in global politics. While the war coincided with the Olympic Games in Beijing and floods in Western Ukraine, it was between top-news in worlds media. The theme of the Caucasus war remained as a \#1 after the declaration of peace (on August 13, 2008). During this war, it was possible to get a better understanding of the events not necessarily taking place in the Caucasus. The war has pushed journalist to update the problem of dual citizenship in Crimea, in particular accordingly the possibility of repetition of such scenario in Ukraine. Ukrainian channel “1+1" prepared a video plot about the owners of Russian passports in Crimea without definitive conclusions (Meshkantsiam Krymu 2008).

The Georgian scenario repeated itself in Ukraine less than in 10 years. Ukrainian authorities and especially the Ukrainian political elite didn't make appropriate conclusions from Russian-Georgian war in 2008, and Ukraine wasn't ready for such development of the situation in Crimea, for instance. As a result, Ukraine lost it and has a "hot point" in the eastern border. But many journalists, experts, and civic activists tried to draw attention to the problem of dual citizenship, Russian military aggression, broken sovereignty of the state etc.

Thereby, the hybrid war between the Russian Federation and Georgia in August 2008 can be considered as an approbation the world society reaction on violations of international law and state sovereignty at the beginning of the XXI century. And further events in Ukraine proved that the reaction could be symmetrical to international security challenges.

\section{Ukrainian Borderlands as the Instrument of Influence (Ukrainian-Russian case)}

Ukraine is a state which has common borders with Moldova, Romania, Poland, Slovakia, Hungary, Belarus, and Russia. Back to the past, Ukrainian borderlands (and not only them) have their own pages in history, economic interests etc. with neighbouring countries. The special attention needs to be paid to the national composition of the population of the Crimea which was actively used by the northern neighbour for military intervention. 
According to 2001 national census data, the unique feature of the ethnonational composition of the population of Crimea was its multi-ethnicity: more than 125 ethnics and nations lived there at that time. Another peculiarity was the high amount of Russians - 56,5\% of the total population. It is more than half of the population. And the result of that was Russian-oriented language in information, social and even political sphere of the Autonomy Republic. Ukrainians were in second place $-24,4 \%$ (around $1 / 4$ of the total population). The third national group of the population was Crimean Tatars $-12,1 \%$ of the population (Pro Kilkist 2001).

As far as we can see, Ukrainians as the titular nation in the state were the second national group in Crimea after Russians. It caused some specific features of the internal policy provided the Autonomy Republic. First of all, it is necessary to point out that the most commonly used language of communication in Crimea is Russian. Just before the occupation Crimea by RF, 90,7\% of pupils studied there in Russia, 6,5\% in Ukrainian, and $2,7 \%$ in Crimean Tatar language. So, even before tragic events of the year 2014 more than $90 \%$ of the total amount of pupils studied in Russian. And more than 99\% learnt it as the school subject (Za Try Roky 2017).

The fact that Crimea got the primarily status for aggressive goals of Russian policy toward Ukraine should not be a surprise for Ukrainian authorities. Factually, during the whole independence period, the messages that "Crimea is Russian", "it was presented by Russia to Ukraine" etc. repeatedly sounded from various sources, ranging from the media and ending by officials. But it did not change the policy of national (Kyiv) authorities for the Crimean autonomy. In our opinion, it looked like the desire to avoid any aggravation of the situation associated with the change of national policy in Crimea.

After the start of the Revolution of Dignity in Ukraine, Russian political rhetoric has acquired a pronounced anti-Ukrainian meaning. All political messages aimed to support the V.Yanukovich regime and to condemn the aspirations of millions of Ukrainian for European integration. The political dialogue between the two states went into a dead end. And Russia has changed its strategy toward Ukraine. In winter 2014, Russian Federation brought so-called "green people" (which in fact were the representatives of Russian military troops) to Ukrainian Crimea. On February, 27, the building of Supreme Council and the Council of Ministers of Crimea were occupied by them. The events unfolded very fast. Till midMarch, 2014, Crimea was under the control of "green people", who, in 
fact, represented the Russian military troops. It led to the proclamation of puppet government which started the preparation for a referendum on state belonging of peninsula very soon.

The Russian and pro-Russian powers in Crimea provided aggressive and simple political propaganda aimed at consolidation the idea of Russianness of Crimea between the citizens of the peninsula (and also the surrounding world). The visual means like billboards, leaflets were used to remind the horrors of the Second World war (like in the situation with Georgia), to demonstrate the advantages of Russia as a homeland for Crimea:

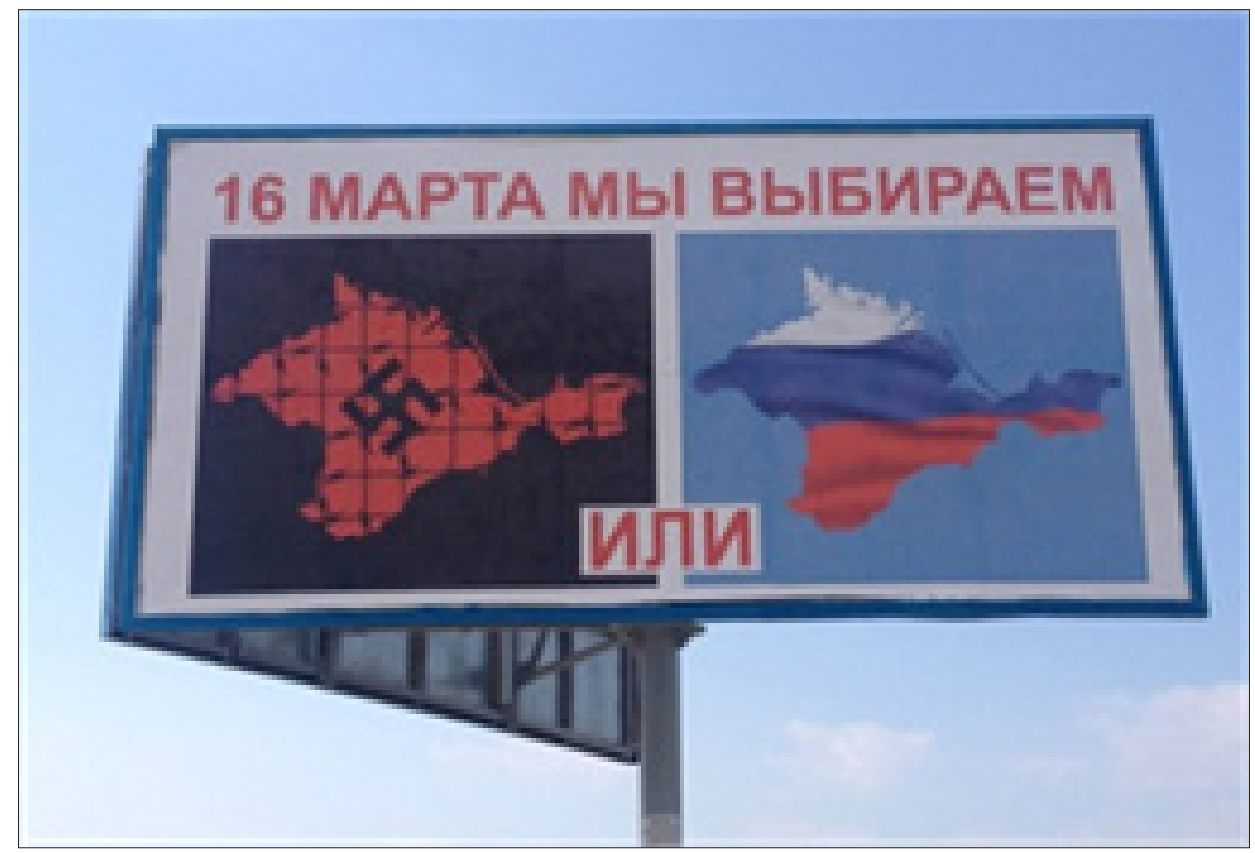

Graphic 2. "On March 16 we choose..."

The military presence of Russian troops and appeal to historical and political stereotypes common with Russian information and cultural space on the peninsula made the results of the referendum predictable. As far as it was announced, around $96 \%$ of the population voted for Russia. By independent data, the results were falsified, but in fact, nobody of Russian authorities took into account the position of independent 
institutes in this case. Soon after the referendum, the peninsula was annexed by Moscow.

At the same time, Russia started military aggression on the eastern borders of Ukraine. It supported the self-proclamation of quasi-states which represent the Russian (or even Soviet Russian) values and policy toward Ukrainian state. The Russian military aggression in the east of Ukraine was provided by the algorithm which was tested at the beginning of XX century when the Ukrainian Socialist Soviet republic with the capital in Kharkiv was proclaimed (1919). But political circumstances and mentality of the people (what is the most important) has changed. For contemporary Russia, it was impossible to ruin Ukrainian independence by political instruments of the last century. But it is necessary to remember that the strategic goal for Russia concerning Ukraine left the same: Ukraine has to be in Russia's sphere of influence. And as far as we can see, the tactical steps are in forward to reach this goal (using pandemic for spreading conspiracy theories of modernity, using Russian Orthodox Church for keeping influence on Ukrainian people, information warfare against Ukraine etc.)

\section{Conclusions}

The borderlands always played a huge role in world politics. Changing borders of states during previous centuries brought to the modernity both an opportunity and a challenge to international security and geopolitics. Borderlands as the territories which are inhabited by people of a different nationality, affect security and stability in the region and even in the world. At the same time, they are in the political spotlight. Political actors are often using them to achieve geopolitical interests.

$\mathrm{XX}$ century focused attention of political actors on principle position: contemporary political leadership is impossible without control on energy, human and military resources. The combination of these components opens up significant space for establishing not only total control in a state, but also provides leadership in world politics. Control over energy resources gives financial and political power; military power can ensure a realization of political interests with traditional instruments of influence. Moreover, control over human resources creates a basis for political 
loyalty and perception of all political activity. Additionally, information tools are really in demand for this.

After the collapse of the USSR, Russian Federation used Soviet heritage in the administrative division for strengthening its influence on former Soviet republics. Transnistria, Abkhazia, South Ossetia, Crimea and eastern regions of Ukraine became the goals and objects of Russian policy. From one point of view, all of them are the tools to cause political instability in newly independent states. But from another, they had to become peculiar agents of influence on themselves.

Crimea became a separate example. It was annexed and included into the Russian Federation very soon. From our point of view, that demonstrates that Russian authorities understood that the political potential of influence of pro-Russian Crimea on Ukraine was exhausted. Therefore, changing borders showed to all (first of all to Ukraine) the power of Russia as the state which can shift state borders at the beginning of the XXI century with violation of international law. It caused the political leaders all over the region (again, first of, all of Ukraine) started to be afraid about the future of their states, because their territorial integrity might get violated.

The last decade brought many new challenges to the surface. And the democratic world is trying to find an appropriate solution to them while maintaining democracy as a political basis. Nowadays, we are not just witnessing the struggle between democracy and authoritarianism. The innovative technologies transformed every person into an active participant of this process, especially those who live in borderlands.

\section{Bibliography}

Administrative map of the Republic of Moldova, http:/ / www.allworldwars.com/Battle\%20for\%20the\%20South\%20Ossetia\%20August\%202008.html (25.06.2020).

A Guide to Coronavirus-Related Words, https://www.merriam-webster.com/words -at-play/coronavirus-words-guide/covid-19 (26.06.2020).

Caucasian region, http://www.allworldwars.com/Battle\%20for\%20the\%20South \%20Ossetia\%20August\%202008.html (25.06.2020).

Coronavirus: What is a pandemic and use the term now? (2020), https:/ / www.bbc.com/ news/health-51358459 (25.06.2020). 
Covid-19 Coronavirus Pandemic, https:/ / www.worldometers.info/coronavirus /?utm_ campaign=homeAdvegas1? (30.06. 2020).

Hromadiany Ukrainy pro bezpeku: otsinky, zahrozy, shliakhy vyrishennia problem. (2015), https: / / www.prostir.ua/ ?news=hromadyany-ukrajiny-pro-bezpeku-otsinky-zahrozy-shlyahy-vyrishennya-problem (27.06.2020).

Ivchenko, B. (2013), Yak rosiys'ka propahanda robyla z Saakashvili Hitlera, “Ukrayins'ka pravda, Istorychna pravda", https:/ / www.istpravda.com.ua/articles/2013 /08 /8/133427/view_print/ (25.06.2020).

Karantyn, zumytys, efpeshka - slova, yaki uviishly u vashu movu pid chas karantynu (2020), https://gazeta.ua/articles/posuti/_karantip-zumitis-efpeshka--slova-yaki-uvijshli-u-vashu-movu-pid-chas-karantinu/960722 (25.06.2020).

Kyrydon, A.M., Troian (2009), Rosiisko-hruzynskyi konflikt serpnia 2008 roku: istoryko-politolohichnyi analiz, Kyiv-Rivne, PIC KCУ, 8080 p.

Kytaiskye Predprynymately daly sovety po borbe s Covid-19 v Rossyy (2020), https:/ / iz.ru/1008855/2020-05-08/kitaiskie-predprinimateli-dali-sovety-po-borbe-scovid-19-v-rossii (28.06.2020).

Meshkantsiam Krymu aktyono vydaiut rosiiski pasporty (video) (2008), http://tsn. ua/ukrayina/meshkantsyam-krimu-aktivno-vidayut-rosiiski-pasporti.html (29.06.2020).

Pro Kilkist ta sklad naselennia Avtonomnoi Respubliky Krym za pidsumkamy Vseukrainskoho perepysu naselennia 2001 roku (2001), http://2001.ukrcensus.gov. ua/results/general/nationality/crimea/ (29.06.2020)

SMY: Uspeshnyi metod borby s koronavyrusom razrabotaly v Kytae (2020), https:// rg.ru/2020/01/23/smi-uspeshnyj-metod-borby-s-koronvirusom-razrabotali-v-kitae.html (28.06.2020).

Russkaya propaganda v Krymu d preddverii referendum. Obeschaniia I real'nost' (2014), https://www.ostro.org/general/politics/articles/440058/ (26.06.2020).

Tuchynskyi, V.A. (2011), Moldavska Avtonomna Radianska Sotsialistychna Respublika u skladi URSR 1924-1940 rr. i administratyvni zminy na terytorii Prydnistrovia, "Naukovi zapysky Vinnytskoho derzhavnoho pedahohichnoho universytetu imeni Mykhaila Kotsiubynskoho. Seriia: Istoriia", 19:255.

U Shtuchne Pokhodzhennia koronavirusu viriat 66\% ukraintsiv - KMIS (2020), https:/ / www.ukrinform.ua/rubric-society/3052653-u-stucne-pohodzenna-koronavirusu-virat-66-ukrainciv-kmis.html (27.06.2020).

U Velykii Brytanii stvoriuiut pidrozdil dlia borotby $z$ rosiiskoiu dezinformatsiieiu pro koronavirus (2020), https://ms.detector.media/media-i-vlada/post /24306/2020-03-10-u-velikii-britanii-stvoryuyut-pidrozdil-dlya-borotbi-z-rosiiskoyu-dezinformatsieyu-pro-koronavirus/ (28.06.2020).

Vostochnoe Povetrye. Kak uspeshnaia borba s koronavyrusom pomozhet Kytaiu pobedyt SShA y stat novym myrovybm lyderom? (2020), https://lenta.ru/articles/2020/04/06/handling_the_pandemic/ (28.06.2020). 
Za Try Roky kilkist uchniv u Krymu, yaki navchaiutsia ukrainskoiu, zmenshylasia u 36 raziv (2017), https:/ / www.ukrinform.ua/rubric-polytics/2220496-za-tri-roki-kilkist-ucniv -u- krimu-aki-navcautsa-ukrainskou-zmensilas-u-36-raziv.html (29.06.2020). 
